\author{
P.O. КОЗАК ${ }^{1}$, П.А. БЕXТА ${ }^{2}$
}

\title{
МАТЕМАТИЧНЕ МОДЕЛЮВАННЯ І ПОРІВНЯЛЬНИЙ АНАЛІЗ ТРИВАЛОСТІ ПРЕСУВАННЯ СТРУЖКОВИХ ПЛИТ НА ОСНОВІ ДЕРЕВИННОЇ ТА СОЛОМ'ЯНОЇ СТРУЖКИ
}

Запропоновано математичну модель тривалості пресування стружкового пакета, яка поєднує фізичні властивості складових компонентів стружкового пакета, готової стружкової плити та параметри режиму пресування. На основі математичної моделі розраховано тривалість пресування стружкових плит із деревинної та солом'яної стружки залежно від температури плит преса, вологості стружкового пакета, щільності й товщини готових плит. Встановлено, що тривалість пресування солом'яного стружкового пакета $\epsilon$ більшою в межах однієї хвилини від тривалості пресування деревинного пакета. Різниця між тривалістю пресування солом'яного і деревинного стружкових пакетів збільшується у разі зниження температури пресування, підвищення щільності й товщини плити та вологості (до 16\%) стружкового пакета. За вологості стружкового пакета більше 16\% вона змінюється несуттєво.

Ключові слова: солом'яна стружка, деревинна стружка, стружковий пакет, стружкова плита, щільність, вологість, температура пресування, тривалість пресування, математична модель

Постановка проблеми. Найважливішими передумовами розвитку виробництва стружкових плит $є$ наявність у країні власної сировини. За дефіциту деревинної сировини i наявності великого обсягу сільськогосподарських целюлозомістких відходів виробництво стружкових плит з використанням злакової соломи може бути досить привабливим [1]. Солом’яні плити здатні мати високі показники властивостей [2] і можуть бути використані для заміни традиційних стружкових плит.

Пресування є завершальною операцією утворення стружкової плити, під час якої розвиваються і завершуються фізичні та хімічні процеси у стружковому

\footnotetext{
${ }^{1}$ КОЗАК Руслан Олегович - доцент кафедри технологій деревинних композиційних матеріалів, целюлози та паперу, кандидат технічних наук, Національний лісотехнічний університет України, м. Львів, Україна. Тел.: 032238-44-99. E-mail: kozak_ruslan@ukr.net

2 БЕХТА Павло Антонович - дійсний член ЛАН України, завідувач кафедри технологій деревинних композиційних матеріалів, целюлози та паперу, доктор технічних наук, професор, Національний лісотехнічний університет України, м. Львів, Україна. Тел.: 032-238-44-99. E-mail: bekhta@ukr.net
} 
пакеті. Саме ця операція найбільше впливає на формування якісних характеристик готової плити [3-5].

Під час пресування солом’яного стружкового пакета його фізичні властивості відрізняються від деревинного [6], що зумовить потребу корегування режиму пресування, встановленого для виготовлення стружкових плит.

3 контрольованих режимних параметрів пресування стружкових плит визначальним є тривалість пресування, оскільки від нього залежать не тільки інші параметри режиму та властивості готових плит, а й продуктивність преса [3]. Тому для виготовлення стружкових плит із солом’яної стружки є потреба у визначенні тривалості пресування солом’яного стружкового пакета. Враховуючи складність фізичних і хімічних процесів, які відбуваються під час пресування стружкових плит, математичне моделювання тривалості пресування солом’яного стружкового пакета є найдоцільнішим. Це дасть змогу не тільки знайти значення цього параметра для різних умов виготовлення стружкових плит, але і теоретично обгрунтувати ці значення, а також здійснити їх аналіз.

Мета роботи - розробити математичну модель тривалості пресування стружкових плит і на її основі здійснити порівняльний аналіз тривалості пресування плит на основі деревинної та солом’яної стружки. Об’єкт досліджень - процес пресування стружкових плит на основі деревинної та солом’яної стружки.

Результати дослідження. Згідно 3 фізико-хімічними процесами, які відбуваються всередині пакета під час пресування стружкових плит, тривалість Ïх пресування залежатиме від тривалості прогрівання середнього шару до температури поліконденсації клею, тривалості затвердіння клею і тривалості випаровування надлишкової вологи зі стружкового пакета. Оскільки здебільшого тривалість випаровування надлишкової вологи з пакета є більшою за тривалість затвердіння клею в середньому шарі пакета i зазначені процеси відбуваються одночасно, то тривалість пресування плит можна записати у вигляді $[7,8]$ 


$$
\tau_{\text {sum }}=\tau_{\text {np }}+\tau_{\text {sun }},
$$

де $\tau_{\text {вuт }}-$ тривалість пресування плит у пресі, хв;

$\tau_{n p}$ - тривалість прогрівання середнього шару плити до температури поліконденсації клею і випаровування вологи, хв;

$\tau_{\text {виn }}$ - тривалість випаровування вологи зі стружкового пакета, хв.

Тривалість випаровування вологи зі стружкового пакета залежить від їі кількості, температури пресування і щільності плити [8]

$$
\tau_{\text {sun }}=(W-8) \cdot K_{t}^{\prime} \cdot K_{\rho}^{\prime},
$$

де $W$ - вологість стружкового пакета, \%;

$K_{t}^{\prime}, K_{\rho}^{\prime}-$ коефіцієнти температури пресування і щільності плит відповідно.

Згідно з табличними даними [8] коефіцієнти температури пресування i щільності плит можуть бути представлені такими залежностями:

$$
\begin{gathered}
K_{t}^{\prime}=0,1071429 \cdot 10^{-3} \cdot t_{n \text { num }}^{2}-0,0461571429 \cdot t_{n \text { num }}+5,4208571429 ; \\
K_{\rho}^{\prime}=3,2857 \cdot 10^{-6} \cdot \rho_{n n}^{2}-2,7228571 \cdot 10^{-3} \cdot \rho_{n n}+1,3846428571 .
\end{gathered}
$$

Тривалість прогрівання середнього шару плити до температури поліконденсації клею і випаровування вологи залежить від теплопровідності сировини і матеріалів, з яких плита складається.

Якщо припустити, що стружковий пакет має вигляд пластини (рис. 1), яка розташована між нагрітими до певної температури плитами $\left(t_{n л u m}\right)$, то згідно 3 відомим законом теплопровідності Фур’є, величина теплового потоку (dQ) прямо пропорційна коефіцієнту теплопровідності ( $\lambda$ ), градієнту температури ( $\frac{d t}{d x}$ ) та площі поверхні матеріалу $(F)$. Математично це можна записати таким чином [9-11]:

$$
\frac{d Q}{d \tau_{n p}}=-\lambda \cdot F \cdot \frac{d t}{d x}
$$




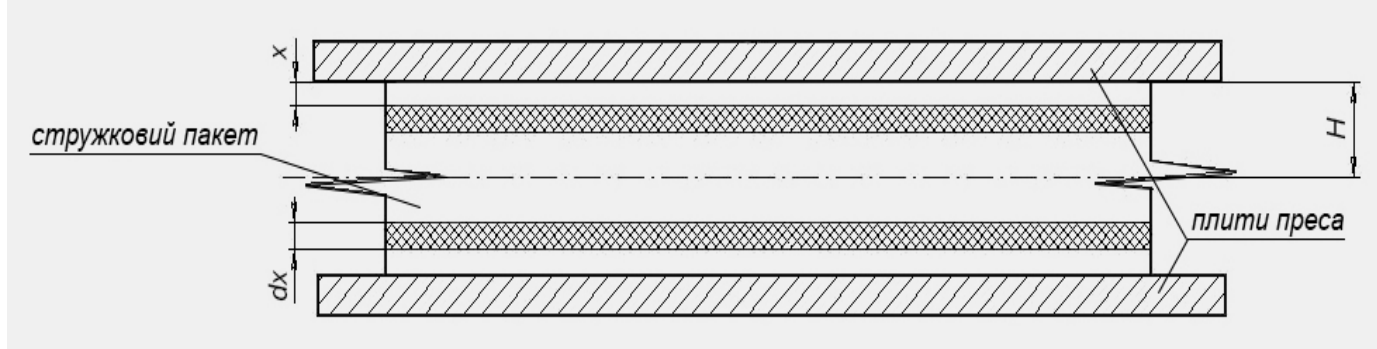

Рис. 1. Схематичне зображення стружкового пакета між плитами преса

Температурний інтервал прогрівання стружкового пакета можна визначити як

$$
d t=t_{\text {c.u. }}-t_{\text {n.u. }},
$$

де $t_{\text {n.ш. }}$ - температура поверхневого шару стружкового пакета (можна прийняти за температуру плит преса $\left.-t_{\text {nлит }}\right),{ }^{\circ} \mathrm{C}$;

$t_{c . u .}$ - температура середнього шару стружкового пакета (можна прийняти за температуру середовища), ${ }^{\circ} \mathrm{C}$.

3 іншого боку, протягом певного часу $(d \tau)$ відбувається прогрівання матеріалу на певну глибину $(d x)$, а кілкість теплоти, яка затрачається на прогрівання матеріалу до відповідної глибини визначається як [9-11]

$$
\frac{d Q}{d \tau_{n p}}=q_{H} \cdot F \cdot \frac{d x}{d \tau_{n p}},
$$

де $q_{н}$ - питома витрата теплоти на нагрівання одиниці об'єму стружкового пакета, Дж/м³.

Прирівнявши рівняння (5) та (7), отримаємо

$$
\lambda \cdot F \cdot \frac{t_{\text {n.u. }}-t_{\text {c.u. }}}{d x}=q_{H} \cdot F \cdot \frac{d x}{d \tau_{n p}}
$$

Якщо проінтегрувати рівняння (8) в інтервалі від 0 до $x$, то можна визначити тривалість прогрівання пакета на глибину $x$ :

$$
\tau_{n p}=\frac{q_{H}}{\lambda \cdot\left(t_{\text {n.u. }}-t_{\text {c.u. }}\right)} \int_{0}^{x} x d x=\frac{q_{H} \cdot x^{2}}{2 \cdot \lambda \cdot\left(t_{\text {n.u. }}-t_{\text {c.u. }}\right)} .
$$

Для того, щоб визначити тривалість повного прогрівання стружкового пакета до потрібної температури, у формулу (9) замість $x$ потрібно підставити значення $H$ (див. рис. 1). 
Оскільки стружковий пакет складається зі стружки, вологи, клею та повітря, то загальний коефіцієнт теплопровідності можна визначати таким чином:

$$
\lambda=\lambda_{\text {м }} \cdot \omega_{м}+\lambda_{\text {кл }} \cdot \omega_{к л}+\lambda_{в} \cdot \omega_{в}+\lambda_{n} \cdot \omega_{n},
$$

де $\lambda_{м}, \lambda_{к л}, \lambda_{s}, \lambda_{n}-$ коефіцієнти теплопровідності стружки, клею, води та повітря, відповідно, Вт/(м $\left.{ }^{\circ} \mathrm{C}\right)$;

$\omega_{м}, \omega_{\kappa л}, \omega_{8}, \omega_{n}-$ об’ємні частки стружки, клею, води та повітря у стружковому пакеті відповідно.

\section{Виразивши об’ємні частки складових стружкового пакета через їх} процентний вміст, формула (10) набуде вигляду

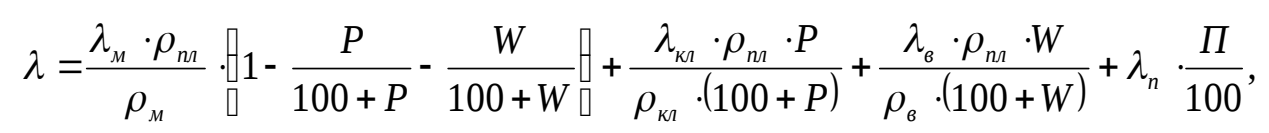

де $\rho_{n л}-$ щільність спресованого стружкового пакета, кг/м³;

$\rho_{м}$ - щільність стружки у спресованому стружковому пакеті, кг/ $\mathbf{M}^{3}$;

$\rho_{\text {кл }}$ - густина клею (затверділого полімеру) у спресованому стружковому

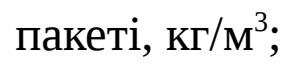

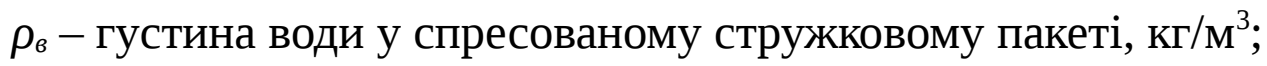

$P$ - процентний вміст клею у спресованому стружковому пакеті, \%;

W - процентний вміст вологи у спресованому стружковому пакеті, \%;

$\Pi$ - пористість у спресованому стружковому пакеті, \%.

Вміст частки вологи в спресованому стружковому пакеті дорівнює [8]

$$
W=\frac{W_{u} \cdot K+P \cdot(100-K)}{K \cdot(100+P)} \cdot 100
$$

де $K$ - концентрація клею, \%;

$W_{ч}$ - вміст частки вологи у стружці, \%

Пористість стружкового пакета можна представити у вигляді [12]

$$
\Pi=1-\rho_{n л} \frac{1}{\left.\rho_{M}\right]}\left[1-\frac{W}{100+W}-\frac{P}{100+P}\right]+\frac{P}{\rho_{\kappa л}(100+P)}+\frac{W}{\rho_{\varepsilon}(100+W)} .
$$

Питому витрату теплоти на нагрівання стружкового пакета визначають за таким рівнням [9-11]: 


$$
q_{н}=\frac{m_{n л}}{V_{n л}} \cdot C_{n л} \cdot\left(t_{n p}-t_{c . u .}\right)=\rho_{n л} \cdot C_{n л} \cdot\left(t_{n p}-t_{c . \text {.u. }}\right)
$$

де $m_{n л}-$ маса стружкового пакета, кг;

$V_{n л}-$ об’єм стружкового пакета; м³;

$C_{n л}$ - питома теплоємність стружкового пакета, кДж/(кг $\left.{ }^{\circ} \mathrm{C}\right)$;

$t_{n p}$ - температура, до якої потрібно прогріти стружковий пакет, ${ }^{\circ} \mathrm{C}$.

Питому теплоємність стружкового пакета можна представити через питомі теплоємності його складових у вигляді

$$
C_{n л}=\frac{m_{M} \cdot C_{M}+m_{\kappa л} \cdot C_{\kappa л}+m_{в} \cdot C_{в}}{m_{n л}},
$$

де $m_{м}, m_{\kappa л}, m_{в}-$ маса стружки, клею і води відповідно, кг;

$C_{м}, C_{\kappa л}, C_{в}-$ питомі теплоємності стружки, клею і води відповідно, кДж/(кг $\left.{ }^{\circ} \mathrm{C}\right)$;

Виразивши маси складових стружкового пакета через їх процентний вміст у ньому, формула (15) набуде такого вигляду:

$$
\left.\left.C_{n л}=C_{M} \cdot\right]_{0}-\frac{P}{100+P}-\frac{W}{100+W}\right]+\frac{C_{\kappa л} \cdot P}{(100+P)}+\frac{C_{в} \cdot W}{(100+W)} .
$$

3 урахуванням виразів (11) i (16) формула тривалості прогрівання стружкового пакета (9) набуде вигляду

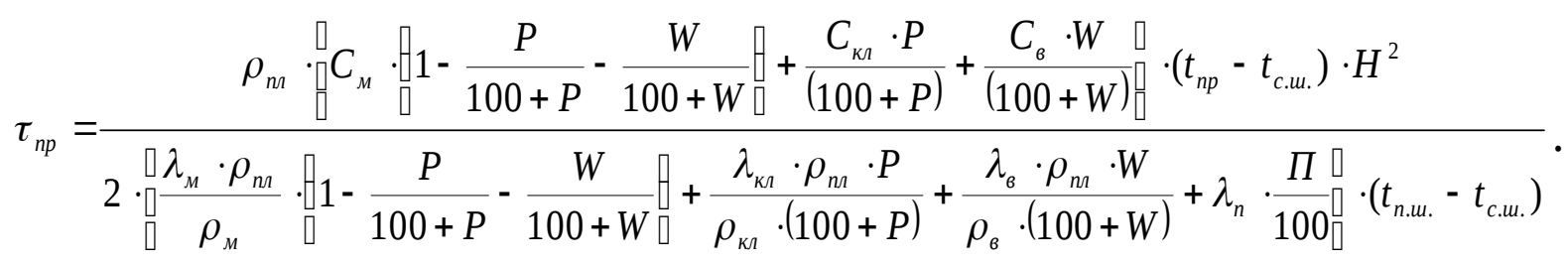

Тоді формула (1) тривалості пресування стружкових плит набуде вигляду

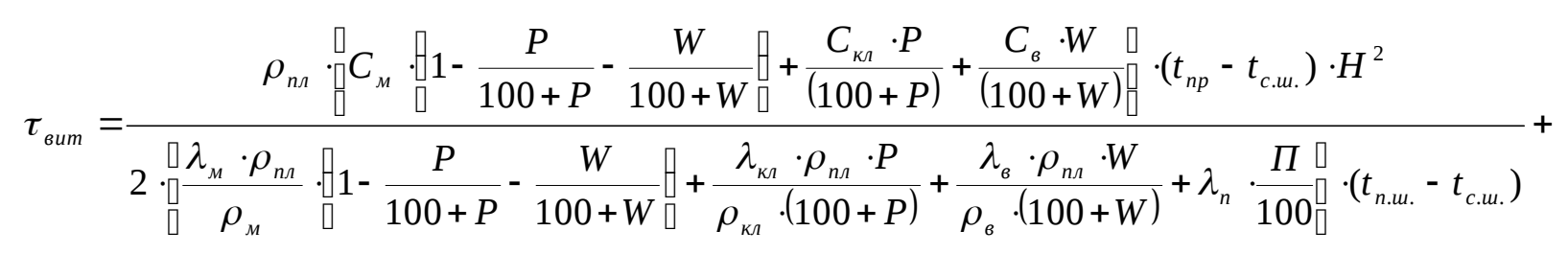

$+(W-8) \cdot K_{t}^{\prime} \cdot K_{\rho}^{\prime}$

Формула (18) дає змогу визначити тривалість пресування стружкових плит залежно від застосовуваної сировини й клею, процентного вмісту в стружковому пакеті компонентів плити, а також температури пресування. 
Основними параметрами, що впливають на тривалість пресування стружкових плит, є: щільність стружкового пакета (готових плит); вологість стружкового пакета; температура пресування (плит преса); товщина готових плит [3, 7, 8, 13]. Тому, на основі запропонованої формули тривалості пресування стружкових плит, здійснено розрахунок значень цього параметра для плит зі злакової соломи залежно від товщини і щільності готових плит, вологості стружкового пакета та температури пресування (табл. 1).

Таблиця 1

Тривалість пресування стружкових плит із злакової соломи

\begin{tabular}{|c|c|c|c|c|c|c|}
\hline \multirow{2}{*}{$\begin{array}{c}\text { Вологість } \\
\text { стружкового } \\
\text { пакета, \% }\end{array}$} & \multirow{3}{*}{$\begin{array}{c}\text { Температура } \\
\text { плит преса, }{ }^{\circ} \mathrm{C} \\
170\end{array}$} & \multicolumn{5}{|c|}{ 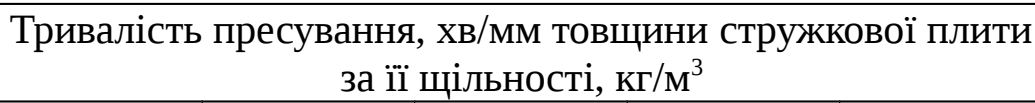 } \\
\hline & & 600 & 650 & 700 & 750 & 800 \\
\hline \multirow{5}{*}{10} & & 0,28 & 0,28 & 0,29 & 0,30 & 0,31 \\
\hline & 180 & 0,25 & 0,26 & 0,27 & 0,27 & 0,28 \\
\hline & 190 & 0,24 & 0,24 & 0,25 & 0,25 & 0,26 \\
\hline & 200 & 0,22 & 0,23 & 0,23 & 0,24 & 0,24 \\
\hline & 210 & 0,21 & 0,22 & 0,22 & 0,23 & 0,23 \\
\hline \multirow{5}{*}{12} & 170 & 0,35 & 0,36 & 0,38 & 0,40 & 0,42 \\
\hline & 180 & 0,32 & 0,33 & 0,35 & 0,36 & 0,38 \\
\hline & 190 & 0,30 & 0,31 & 0,32 & 0,33 & 0,35 \\
\hline & 200 & 0,28 & 0,29 & 0,30 & 0,31 & 0,32 \\
\hline & 210 & 0,26 & 0,27 & 0,28 & 0,29 & 0,31 \\
\hline \multirow{5}{*}{14} & 170 & 0,42 & 0,44 & 0,46 & 0,49 & 0,52 \\
\hline & 180 & 0,38 & 0,40 & 0,42 & 0,44 & 0,47 \\
\hline & 190 & 0,35 & 0,37 & 0,38 & 0,40 & 0,42 \\
\hline & 200 & 0,33 & 0,34 & 0,36 & 0,37 & 0,39 \\
\hline & 210 & 0,31 & 0,32 & 0,34 & 0,36 & 0,37 \\
\hline \multirow{5}{*}{16} & 170 & 0,49 & 0,52 & 0,54 & 0,58 & 0,61 \\
\hline & 180 & 0,44 & 0,46 & 0,49 & 0,52 & 0,55 \\
\hline & 190 & 0,40 & 0,42 & 0,45 & 0,47 & 0,50 \\
\hline & 200 & 0,38 & 0,39 & 0,41 & 0,44 & 0,46 \\
\hline & 210 & 0,36 & 0,37 & 0,39 & 0,42 & 0,44 \\
\hline \multirow{5}{*}{18} & 170 & 0,56 & 0,59 & 0,62 & 0,66 & 0,71 \\
\hline & 180 & 0,50 & 0,53 & 0,56 & 0,59 & 0,63 \\
\hline & 190 & 0,46 & 0,48 & 0,51 & 0,54 & 0,57 \\
\hline & 200 & 0,42 & 0,44 & 0,47 & 0,50 & 0,53 \\
\hline & 210 & 0,40 & 0,42 & 0,45 & 0,47 & 0,50 \\
\hline
\end{tabular}

Графічні залежності тривалості пресування стружкових плит зі злакової соломи від зазначених основних параметрів наведено на рис. 2-4. 
Згідно $з$ даними рис. 2, 3 підвищенням температури плит преса тривалість пресування зменшується. Це пов'язано зі швидшим прогріванням пакета та випаровуванням 3 нього надлишкової вологи. Зі збільшенням вологості стружкового пакета вплив температури пресування зростає, що пов'язано із кращою теплопровідністю води, порівняно зі соломою, клеєм та повітрям. Зокрема, за вологості стружкового пакета 10\% і зміни температури пресування від $170^{\circ} \mathrm{C}$ до $210^{\circ} \mathrm{C}$ тривалість пресування зменшується від 5,28 хв до 4,00 хв або на 31,9\%, тоді як за вологості пакета $18 \%$ за аналогічної зміни температури тривалість пресування зменшується від 11,22 хв до 8,02 хв або на $39,8 \%$.

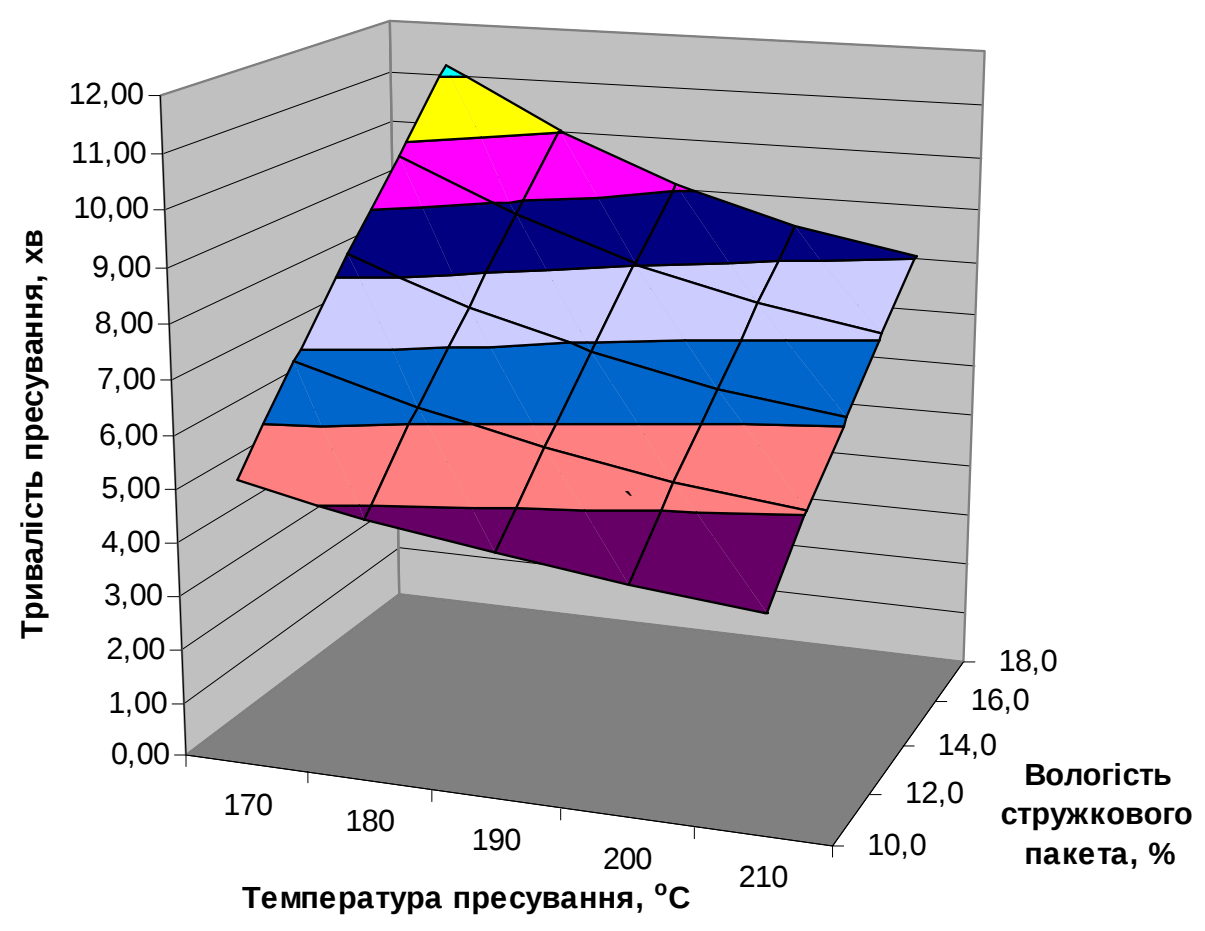

\section{Рис. 2. Залежність тривалості пресування стружкових плит із соломи злаків від температури пресування та вологості пакета (товщина плити 18 мм; щільність плити 700 кг/м³)}

Збільшення вологості стружкового пакета за незмінної температури пресування спричиняє різке збільшення тривалості пресування, тому що потрібно більше часу на випаровування вологи. У разі зміни вологості стружкового пакета від $10 \%$ до $18 \%$ за температури пресування $170^{\circ} \mathrm{C}$ і $210^{\circ} \mathrm{C}$ тривалість пресування збільшується на 112,6\% і 100,6\% відповідно, тобто 
більше як у два рази. Отже, на тривалість пресування вологість стружкового пакета впливає більше, ніж температура пресування. Зокрема, у досліджуваних межах зміна температури пресування змінюе тривалість пресування максимально на 39,8 \%, тоді як вологості стружкового пакета - на 112,6\%.

Зростання щільності готових плит і зменшення температури пресування збільшує тривалість пресування (рис. 3). Зокрема, в разі зміни щільності плити від $600 \mathrm{\kappa г} / \mathrm{M}^{3}$ до $800 \mathrm{kг} / \mathrm{M}^{3}$ за температури пресування $170^{\circ} \mathrm{C}$ і $210^{\circ} \mathrm{C}$ тривалість пресування збільшується на 22,0\% (від 7,63 хв до 9,31 хв) і 20,6\% (від 5,59 хв до 6,75 хв) відповідно. Це пов’язано зі зростанням кількості матеріалу і вологи в одиниці об’єму стружкового пакета, який потрібно прогріти до температури затвердіння клею.

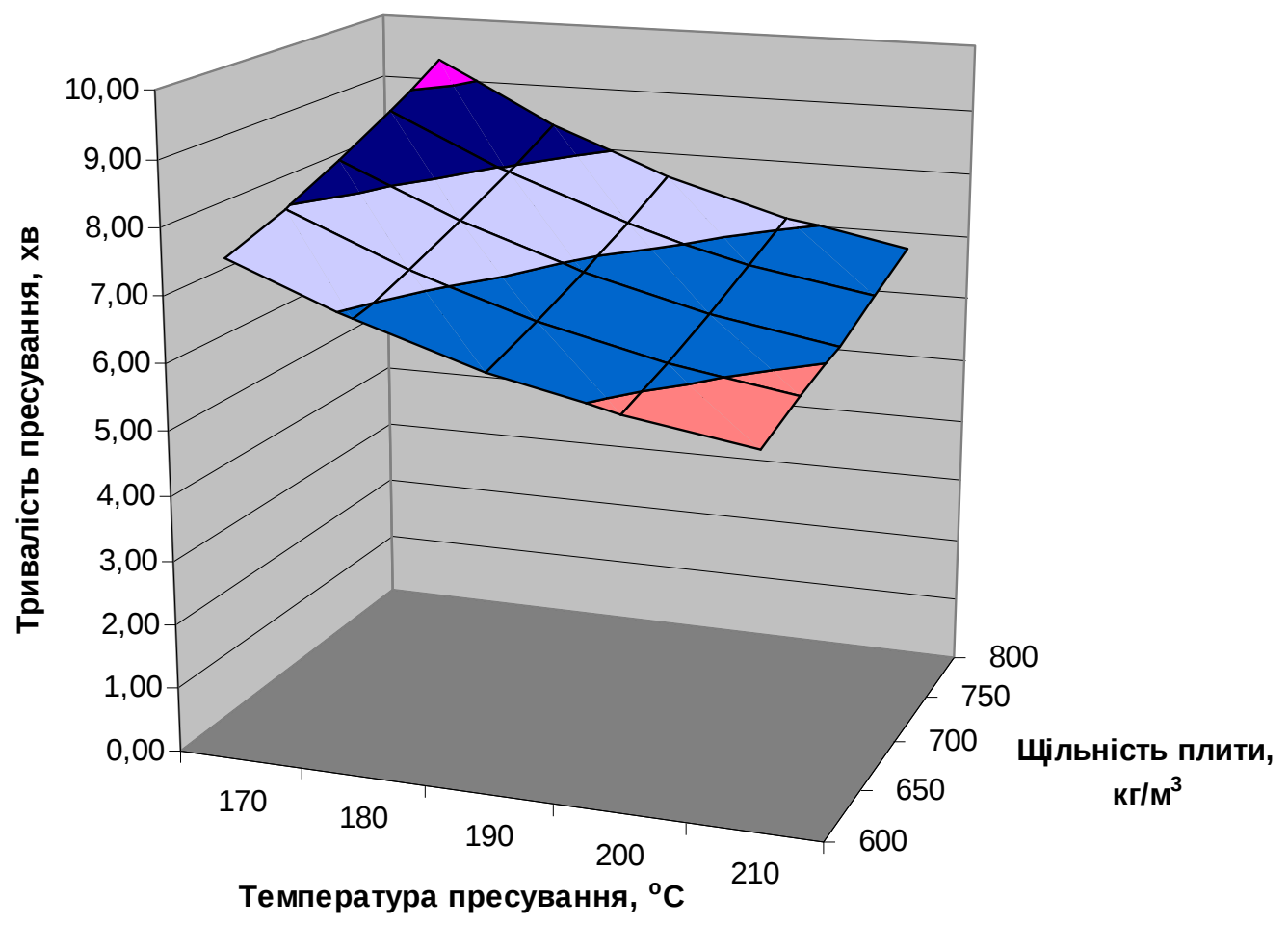

Рис. З. Залежність тривалості пресування стружкових плит зі соломи злаків від температури пресування та щільності плити (вологість пакета $14 \%$; товщина плити 18 мм) 
Зі зростанням товщини плит і зменшенням температури пресування тривалість пресування збільшується (рис. 4). Зокрема, у разі зростання товщини плит від 14 мм до 22 мм за температури пресування $170^{\circ} \mathrm{C}$ тривалість пресування збільшується від 6,78 хв до 10,31 хв, а за температури $210^{\circ} \mathrm{C}-$ від 4,85 хв до 7,64 хв. Це відбувається через збільшення кількості матеріалу по товщині плити, який потрібно прогріти.

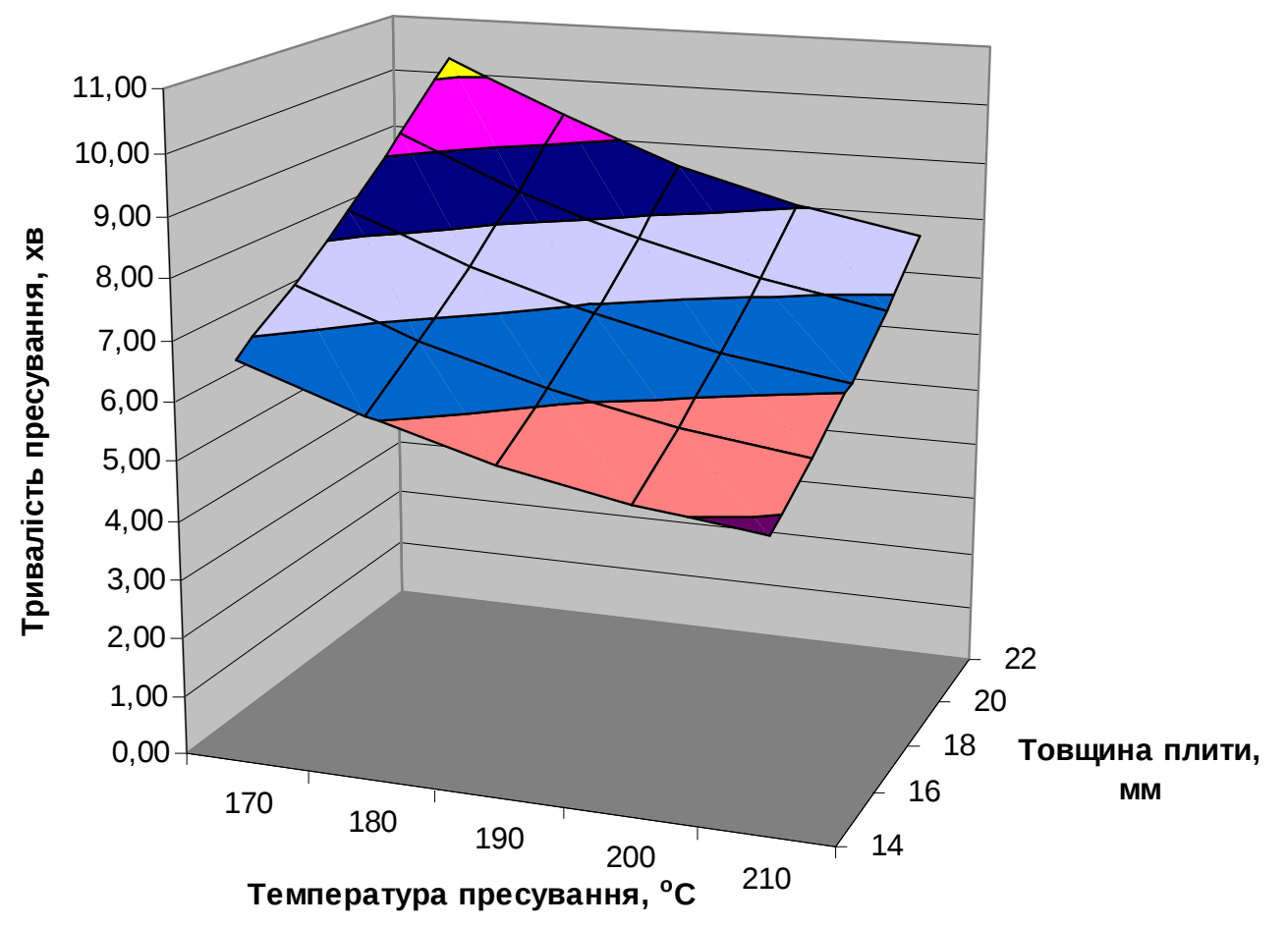

\section{Рис. 4. Залежність тривалості пресування стружкових плит зі соломи злаків від температури пресування та товщини плити (вологість пакета $14 \%$; щільність плити 700 кг/м³)}

Отже, для зменшення тривалості пресування стружкових плит потрібно зменшувати вологість стружкового пакета, щільність готових плит і їх товщину та підвищувати температуру пресування. При цьому на тривалість пресування зазначені фактори збільшують свій вплив у такій послідовності: щільність готової плити; температура пресування; товщина готової плити; вологість стружкового пакета.

Часткова або повна заміна деревинної сировини солом'яною на підприємствах з виготовлення стружкових плит потребуватиме коректування існуючих значень тривалості їх пресування. Порівняльний аналіз тривалості 
пресування деревинного та солом’яного стружкових пакетів дасть змогу встановити відмінності абсолютних значень тривалості пресування цих пакетів й запропонувати рекомендації щодо їх коректування.

На основі виведеної формули (18) отримано значення тривалості пресування деревинного та солом’яного стружкових пакетів і встановлено динаміку відмінностей цього показника за різних значень температури пресування, щільності й товщини плити та вологості пакета, які представлені на рис. 5-8. Розраховані значення тривалості пресування деревинного стружкового пакета добре узгоджуються 3 рекомендованими значеннями тривалості пресування стружкових плит без парового удару $[7,8]$, що підтверджує адекватність формули (18).

Згідно $з$ рис. 5-8, тривалість пресування солом’яного пакета $є$ дещо більшою за тривалість пресування деревинного пакета, що зумовить зниження продуктивності лінії пресування плит зі солом’яною стружкою. Однак для всіх досліджуваних факторів ці зміни тривають не більше 1 хв.

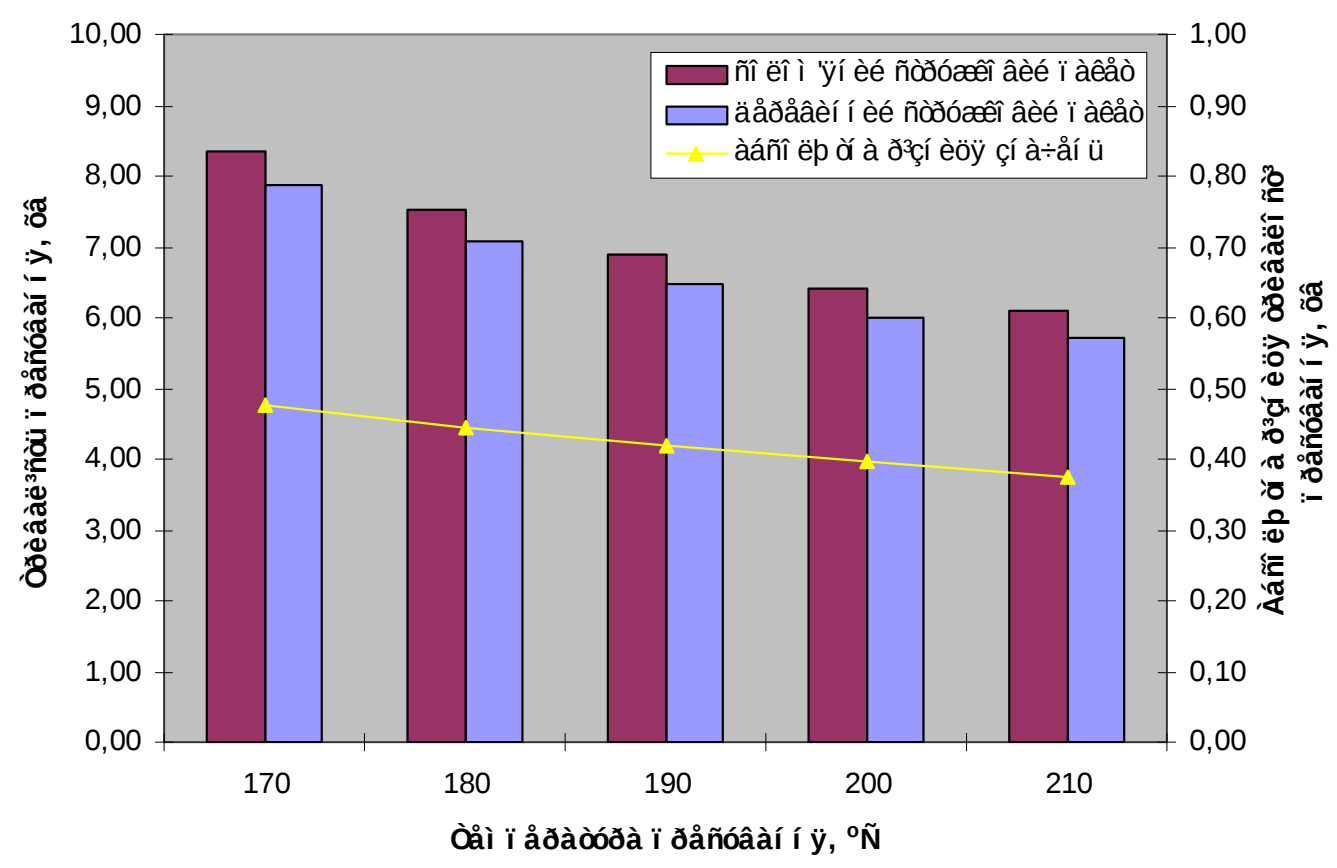

Рис. 5. Значення тривалості пресування солом'яного і деревинного стружкових пакетів та їх абсолютна різниця за різних температур пресування (вологість пакета $14 \%$; щільність плити 700 кг/м³; товщина плити 18 мм) 


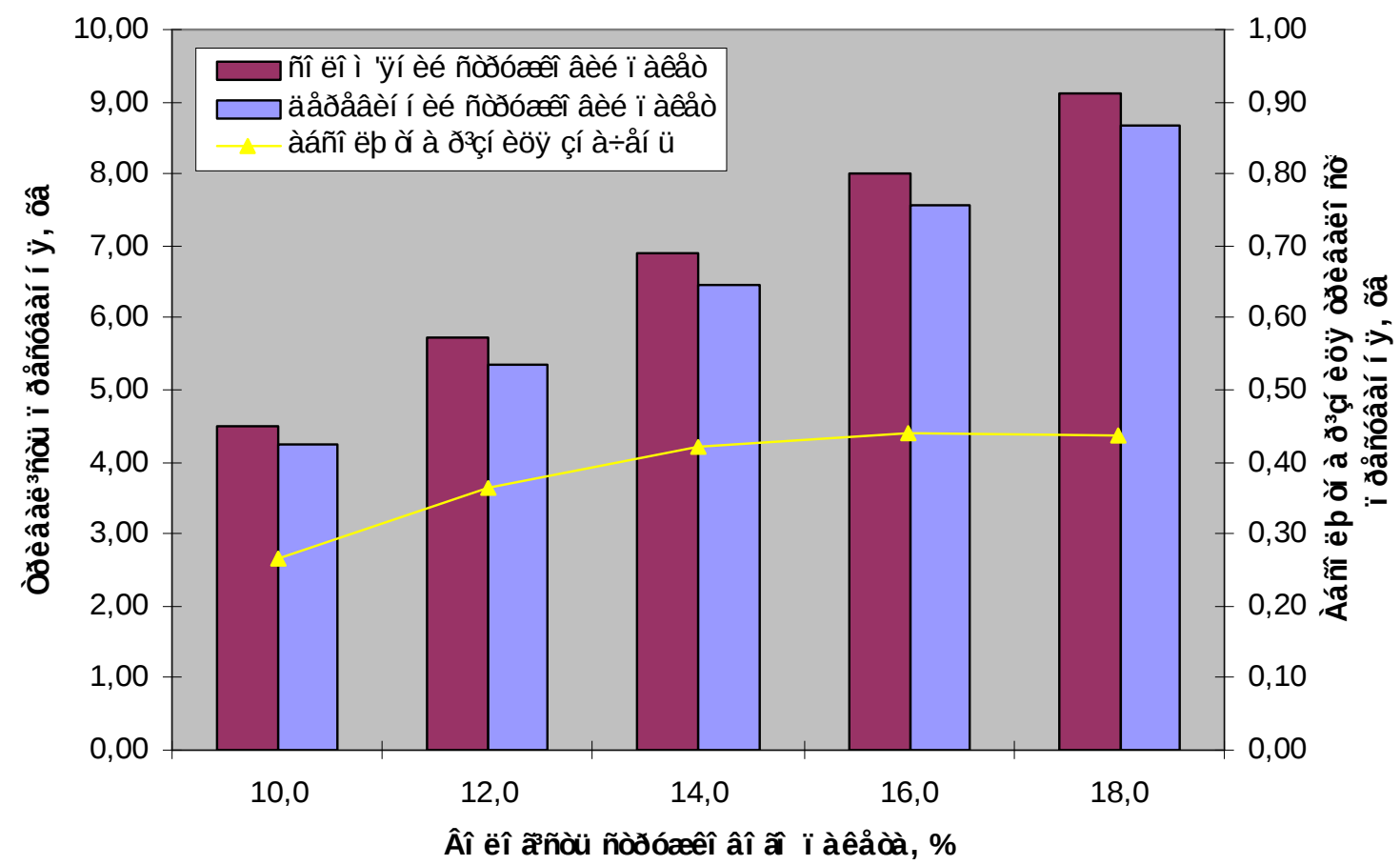

Рис. 6. Значення тривалості пресування солом'яного і деревинного стружкових пакетів та їх абсолютна різниця за різної вологості пакета (температура пресування $190^{\circ} \mathrm{C}$; щільність плити $700 \mathrm{kг} / \mathrm{M}^{3}$;

товщина плити 18 мм)

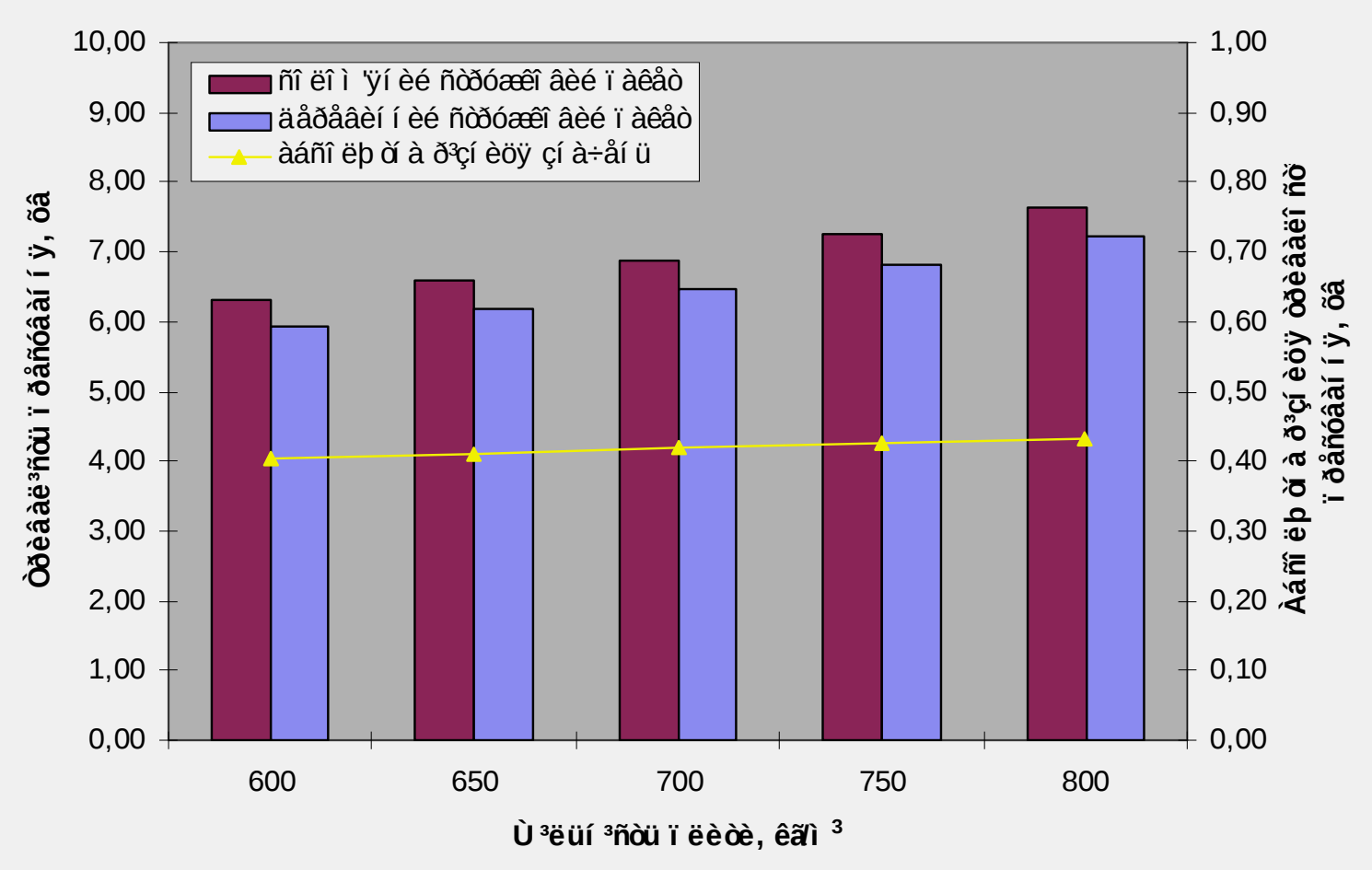

Рис. 7. Значення тривалості пресування солом'яного і деревинного стружкових пакетів та їх абсолютна різниця за різної щільності плити (температура пресування $190^{\circ} \mathrm{C}$; вологість пакета $14 \%$;

товщина плити 18 мм) 


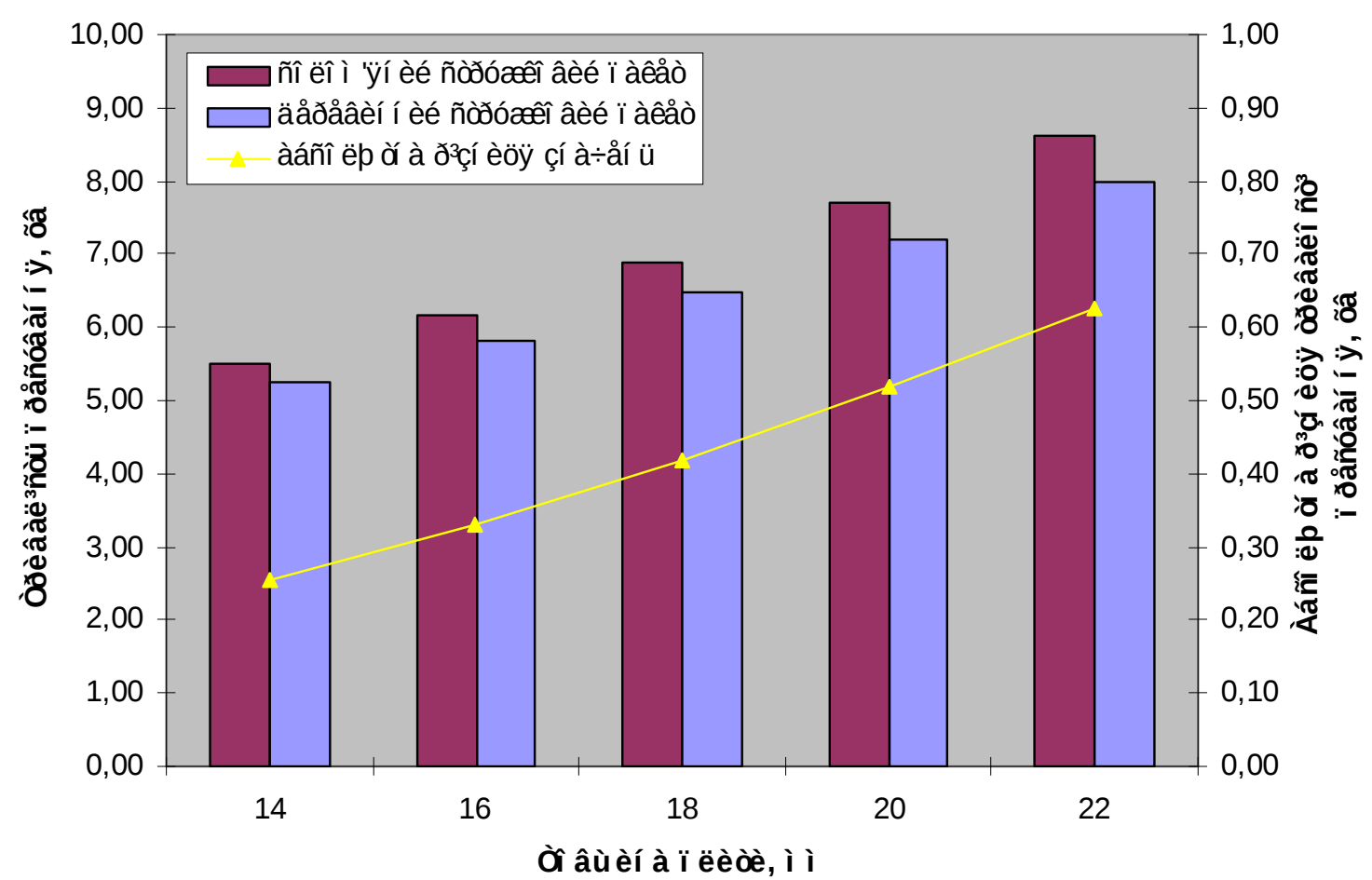

Рис. 8. Значення тривалості пресування солом'яного і деревинного стружкових пакетів та їх абсолютна різниця за різної товщини плити (температура пресування $190^{\circ} \mathrm{C}$; вологість пакета $14 \%$; щільність плити 700 кг/м³)

Підвищення температури пресування зменшує різницю у тривалості пресування солом'яного i деревинного стружкових пакетів (див. рис. 5). Залежність є близькою до прямолінійної і в діапазоні температур від $170^{\circ} \mathrm{C}$ до $210^{\circ} \mathrm{C}$ ця різниця зменшується від 0,48 хв до 0,38 хв. Отже, підвищенням температури пресування можна частково компенсувати зростання тривалості пресування солом’яного пакета.

Різниця у тривалості пресування солом'яного і деревинного стружкових пакетів зі збільшенням вологості пакета у досліджуваному діапазоні змінюється за непрямолінійною залежністю (див. рис. 6). За збільшення вологості пакета до $16 \%$ ця різниця зростає від 0,27 хв до 0,44 хв, а в разі подальшого збільшення вологості пакета до 18\% значення різниці у тривалості пресування солом'яного і деревинного стружкових пакетів практично не змінюється і дорівнює 0,44 хв. Це свідчить про те, що зв'язана волога зі солом'яної стружки видаляється довше порівняно з деревиною. Видалення ж вільної вологи із деревинного і 
солом’яного стружкових пакетів відбувається однаково. Тому для зменшення різниці у тривалості пресування деревинного і солом’яного стружкових пакетів солом’яна стружка повинна бути сухішою за деревинну.

Зі збільшенням щільності та товщини плити різниця у тривалості пресування солом’яного і деревинного стружкових пакетів зростає. Однак, за

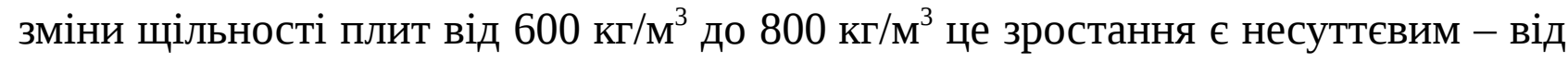
0,40 хв до 0,43 хв (рис. 7), а за зміни товщини плити від 14 мм до 22 мм найбільше серед досліджуваних факторів - від 0,25 хв до 0,63 хв (рис. 8). В обох випадках на результат впливають теплопровідності компонентів плити та їх кількість у ній.

Висновки. Розраховані згідно з виведеною математичною моделлю значення тривалості пресування деревинного стружкового пакета добре узгоджуються 3 рекомендованими в літературі значеннями тривалості пресування стружкових плит. Порівнюючи значення тривалості пресування солом’яного і деревинного стружкових пакетів, встановлено, що тривалість пресування солом'яного стружкового пакета є більшою в межах однієї хвилини i в умовах виробництва призведе до зниження продуктивності лінії виготовлення стружкових плит. Різницю у тривалості пресування солом’яного і деревинного стружкових пакетів можна усунути зменшенням вологості солом’яного стружкового пакета, товщини та щільності готових плит i підвищенням температури пресування.

За динамікою зміни тривалості пресування деревинного і солом’яного стружкових пакетів від температури пресування, щільності й товщини плити та вологості стружкового пакета визначено, що в досліджуваному діапазоні за зростання температури пресування тривалість пресування солом’яного стружкового пакета зменшується швидше, ніж деревинного на 20,8\%, за зменшення щільності й товщини плити - на 7\% й 60,3\% відповідно, а за зменшення вологості стружкового пакета - на 38,6\%, що пов’язано з різною зміною структури та фізичних властивостей солом’яного i деревинного стружкових пакетів. 
Математично змодельована, визначена i проаналізована тривалість пресування стружкових плит із деревинної і солом'яної стружки дасть змогу підвищити ефективність технології виготовлення стружкових плит як 3 деревини, так і зі залученням солом’яної сировини.

\section{СПИСОК ВИКОРИСТАНИХ ДЖЕРЕЛ}

1. Bowyer J. Agricultural residues: an exciting bio-based raw material for the global panels industry / J. Bowyer, V. Stockmann // Forest Products Journal. - 2001. - № 51(1). - P. 10-21.

2. Grigoriou A. Straw-wood composites bonded with various adhesive systems / A. Grigoriou // Wood Science and Technology. - 2000. - № 34. - P. 355365.

3. Бехта П.А. Технологія деревинних плит і пластиків : підруч. [для студ. вищ. навч. закл.] / Бехта П.А. - К. : Основа, 2004. - 780 с.

4. Humphery P. The hot pressing of dry-formed wood-based composites. Part II: a simulation model for heat and moisture transfer, and typical results / P. Humphery, A. Bolton // Holzforschung. - 1989. - № 43(3). - P. 199-206.

5. Dai C. Modeling vertical density profile in wood composite boards / C. Dai, C. Yu, P. Hubert // Proceedings of the 5th Pacific rim bio-based composites symposium. - Canberra, 2000. - P. 220-226.

6. Dai C. Comparison of the pressing behaviour of wood particleboard and strawboard / C. Dai, W. Wasylciw, J. Jin // Wood Science and Technology. - 2004. № 38 - P. 529-537.

7. Бехта П.А. Технологія і обладнання для виробництва деревинностружкових плит : навч. посіб. [для студ. вищ. навч. закл.] / Бехта П.А. - К. : ІСДО, 1994. - 456 с.

8. Бехта П.А. Технологічні розрахунки у виробництві деревинностружкових плит : навч. посіб. [для студ. вищ. навч. закл.] / Бехта П.А. - К. : ІСДО, 1994. - 160 с.

9. Білей П.В. Теоретичні основи теплової обробки і сушіння деревини: моногр. / Білей П.В. - Коломия : Вік, 2005. - 360 с.

10. Теорія теплової обробки деревини : моногр. / [Білей П.В., Кунинець Є.П., Соколовський І.А. та ін.]; за ред. П.В. Білея. - Львів : ЗУКЦ, 2012. - 200 с. 
11. Озарків І.М. Основи аеродинаміки і тепломасообміну : навч. посіб. [для студ. вищ. навч. закл.] / Озарків І.М., Сорока Л.Я., Грицюк Ю.І. - К. : I3MH, 1997. - 280 c.

12. Bekhta P.A. Porosity of Particleboards / P.A. Bekhta, R.O. Kozak // Adhesives in Woodworking Industry : proceedings of the XII Symposium. - Zvolen, 1995. - P. 77-80.

13. Шварцман Г.М. Производство древесностружечных плит / Г.М. Шварцман, Д.А. Щедро. - 4-е изд., перераб. и доп. - М. : Лесн. пром-сть, 1987. 320 c.

\author{
Р.О. Козак, П.А. Бэхта
}

\title{
МАТЕМАТИЧЕСКОЕ МОДЕЛИРОВАНИЕ И СРАВНИТЕЛЬНЫЙ АНАЛИЗ ПРОДОЛЖИТЕЛЬНОСТИ ПРЕССОВАНИЯ СТРУЖЕЧНЫХ ПЛИТ НА ОСНОВЕ ДРЕВЕСНОЙ И СОЛОМЕННОЙ СТРУЖКИ
}

Производство стружечных плит с использованием злаковой соломы может быть достаточно привлекательным при дефиците древесного сырья и наличия большого объема сельскохозяйственных целлюлозосодержащих отходов. Учитывая некоторые различия физических свойств соломы и древесины, можно предположить, что продолжительность прессования соломенного стружечного пакета отличается от установленной для изготовления стружечных плит. А поэтому для изготовления стружечных плит из соломенной стружки есть необходимость в определении продолжительности прессования соломенного стружечного пакета. Учитывая сложность физических и химических процессов, которые происходят при прессовании стружечных плит, математическое моделирование продолжительности прессования соломенного стружечного пакета является наиболее целесообразным. Это позволит не только найти значения этого параметра при различных условиях изготовления стружечных плит, но и теоретически обосновать эти значения, а также осуществить их анализ.

На основе уравнений теплопроводности Фурье и расхода теплоты на прогрев материала предложена математическая модель продолжительности прогрева стружечного пакета на определенную толщину. Модель сочетает физические свойства составляющих компонентов стружечного пакета, готовой стружечной плиты и параметры режима прессования. На основе математической модели рассчитана продолжительность прессования стружечного пакета из злаковой соломы в зависимости от температуры плит 
пресса, влажности стружечного пакета, плотности и толщины готовых стружечных плит. Установлено, что указанные параметры увеличивают свое влияние на продолжительность прессования стружечного пакета в такой последовательности: плотность готовых стружечных плит, температура плит пресса, толщина стружечных плит, влажность стружечного пакета. В исследуемых интервалах переменных параметров продолжительность прессования меняется на 22\% для плотности стружечных плит, на 39,8\% - для температуры плит пресса, на 52\% - для толщины плит и на 112,6\% - для влажности стружечного пакета. Также проведено сравнение продолжительности прессования древесного и соломенного стружечных пакетов. Определено, что продолжительность прессования соломенного стружечного пакета больше в пределах одной минуты от продолжительности прессования древесного стружечного пакета. Разница между продолжительностью прессования соломенного и древесного стружечных пакетов увеличивается при снижении температуры прессования, увеличении плотности и толщины стружечной плиты и увеличении влажности стружечного пакета до 16\%. При влажности стружечного пакета более $16 \%$ разница между продолжительностью прессования соломенного и древесного стружечных пакетов меняется незначительно.

Итак, на основе созданной математической модели определена и проанализирована продолжительность прессования стружечных плит из древесной и соломенной стружки. Это позволит повысить эффективность технологии изготовления стружечных плит с использованием соломы.

Ключевые слова: соломенная стружка, древесная стружка, стружечный пакет, стружечная плита, плотность, влажность, температура прессования, продолжительность прессования, математическая модель

\section{R. Kozak, P. Bekhta}

\section{MATHEMATICAL MODELING AND COMPARATIVE ANALYSIS OF PRESSING TIME OF PARTICLE BOARDS BASED ON WOOD AND STRAW PARTICLES}

Particle board production using cereal straw can be quite attractive due to lack of wood raw material and the presence of large amounts of agricultural waste which include cellulose. After considering several differences between physical properties of straw and wood it can be assumed that the pressing time of straw particle sandwich differs from the established for manufacturing particle board. That's why the particle board production made of the straw particles need to determine the time of baling of straw particle sandwich. Taking info account the 
complexity of the physical and chemical processes that occur during particle board compression, mathematical modeling of the pressing time of the straw particle board package is the most appropriate. This will allow not only to find the value of this setting under different conditions of production of particle board, but also theoretically justify these values, as well as to carry out their analysis.

On the basis of the Fourier heat equations and the heat consumption for the material heating, mathematical model of the heating time of the particle sandwich to a certain thickness was offered. The model combines the physical properties of the components of the particle sandwich, finished particle board and compression mode settings. Based on the mathematical model, the time of particle sandwich made of cereal straw pressing was calculated depends of the temperature of the press platens, the humidity of the particle sandwich, particle sandwich density and thickness of the finished particle board. It is found that these parameters increase its influence on the pressing time of the particle sandwich in the following sequence: the density of the finished particle board, the temperature of the press platens, the thickness of particleboard, moisture of particle sandwich. In the investigated ranges of variable parameters, the pressing time changed to $22 \%$ for the particle board density, $39.8 \%$ for the temperature of the press platens, $52 \%$ for the thickness of the plates and $112.6 \%$ for the humidity of the particle sandwich. Also, a comparison of the pressing time of the straw and wood particle sandwiches was held. It is determined, that the pressing time of straw particle sandwich is higher within one minute from the pressing time of wood particle sandwich. The difference between the pressing time of straw and wood particle sandwiches increases with decreasing of the temperature of pressing, the increasing of the density and thickness of the particle board and the increasing of the humidity of the particle sandwich up to $16 \%$. When the humidity of the particle sandwich is more than $16 \%$ the difference between the pressing time of straw and wood particle sandwich varies slightly. Therefore based on the established mathematical model the pressing time of particle board made of the wood particles and straw was identified and analyzed. This will increase the efficiency of the technology of manufacturing the particle boards with straw.

Key words: straw particles, wood particles, particle sandwich, particle board, density, moisture, pressing temperature, pressing time, mathematical model 